\title{
Euroisation in the Western Balkans: The Evidence for Macedonian Economy
}

\author{
Tatjana Boshkov, PhD1* \\ Zoran Temelkov, $\mathrm{PhD}^{1}$
}

Aleksandra Zezova, $\mathrm{PhD}^{1}$

\begin{abstract}
1Ass.Professors at Faculty of Tourism and Business Logistics, University "Goce Delcev", Stip Email: tatjana.boskov@ugd.edu.mk,zoran.temelkov@ugd.edu.mk,aleksandra.zezova@ugd.edu.mk ${ }^{*}$ Corresponding Author Email: tatjana.boshkov@gmail.com
\end{abstract}

Doi:10.5901/mjss.2017.v8n2p307

\section{Abstract}

Euroisation is a problem with a long history and usually persistent phenomena. The high level of euroisation is common in emerging countries in Europe as in the countries with fixed exchange rate regime. In Western Balkan countries have been identified a strong presence of foreign currency. The fact is that transactions could take a place outside of the banking channels, which is not a case for FX-loan and FX-deposit ratios. It's difficult to measure how much foreign money is in the economy. This is the reason to use data for currency substitution index. This index is high for Macedonia indicating high level of real euroisation. After the crisis, the levels are reduced (lower remittances from abroad). Considering the exchange rate experience of Macedonia, it's likely to remain significantly euroised country for an extended period. IMF considers appropriate strategy which provides support for the gradual de-euroisation in maintaining macro-prudential policy and development of the domestic market. Another important strategy is the maintenance of prudent policies that mitigate foreign currency risks. The paper shows the persistence of FX mainly in Macedonian economy and discusses about benefits and costs, in light of the recent economic crisis.

Keywords: euroisation, de-euroisation, currency, benefits, Macedonia.

\section{Introduction}

The term euroisation implies different monetary systems that use foreign currency as means of payment. Until the establishment of the European Monetary Union, the dollar is the most widespread international reserve currency. This function is assumed by the euro in 2002 (Boshkov, 2015). The level of dollarization or euroisation couldn't be calculated accurately. IMF replies data where half USD dollars are outside the US in turnover, approximately, while in the middle of 90 's the Deutsche Bundesbank estimated that foreigners hold more than $40 \%$ of the output value of the German Mark (DEM).

The number of world currencies is rapidly shrinking in the last decade. With the creation of EMU, many economists believe in existing real prospects for the future in moving a world with two or three currency blocks (in the euro and the dollar, the question arises whether the third world currency will be Japanese Yen or Chinese Yuan). The euro is increasingly becoming an international currency. So today, according to the IMF, 40 countries have exchange rate regime which is pegged to the euro.

The process of euroisation in the Western Balkans is connected with the past macroeconomic and political instability, as the trust in the law and state institutions, too. Thus, the new created democratic countries were facing with the process of transition. In the region are present de jure and de facto euroisation (Bishev and Boshkov, 2015).

For example, Kosovo and Montenegro have unilateral euroisation (they live their independent monetary policy). The high level of euroisation is common in emerging countries in Europe as in the countries with fixed exchange rate regime. European countries have a higher degree of euroisation around at $60 \%$ on average, compared to $25-30 \%$ in Latin America and 5-10\% in East Asia (IMF, 2015).

\section{Pros and Cons of Euroisation Identified in the Literature}

Proponents of euroisation point a number of advantages bringing it in the form of reduced interest rates, increased 
currency stability (because of low inflation), reduced transaction costs and volatility in exchange rates, thus stimulating foreign trade and facilitating the implementation of structural reforms.

a. Decline in interest rates

Decline of interest rate is expected by the process of euroisation. Also, there are expectations to stabilize short-term interest rate, which will be defined by the monetary policy of ECB and stabilization of exchange rate, too. This means that, the imbalance between aggregate supply and demand will be eliminated through the profit and the prices. In the long run, euroisation has no effect on long-term interest rates, because they are determined by savings, investment and risk of outstanding debts. If in the country there is no wage and price flexibility, the short-term effect of reducing the foreign exchange rate risks will result in increasing the cost of borrowing, thus increasing the risk of non-realization of cash obligations, too (Bishev and Boshkov, 2015).

b. Reduction of transaction costs and elimination of exchange rate volatility

Another expected advantage of unilateral euroisation is the elimination of exchange rate volatility and reduced transaction costs from the currency exchange. This advantage creates opportunities for increasing the level of international trade and economic growth. The reduction of transaction costs and the elimination of foreign exchange risk contribute to raise the economic integration with euroised countries, i.e. EMU, since all transactions are exempt from exchange rate risk.

c. Reducing the inflation rate

In some way, euroisation can be considered as anti-inflator strategy. Regardless of the money supply and exchange rate policies which are no longer under the authority of the national central bank, all empirical studies show that application of full euroisation makes a decline in the inflation rate. In the short-term due to the equalization of the prices it can lead to inflation growth, and in the long run, will come to an equalization of inflation between euroised countries and countries whose currencies are used.

If the economy is adjusted to a certain level of inflation, the reduction of the real money supply will have an adverse effect on the rate of economic growth and employment, and increasing the monetary stability will improve economic conditions and will make the country more attractive to foreign investors (Boshkov, 2015). Also, there will be no equivalence between all prices due to controlling the prices, so the effects of euroisation could be determined in the long run. Euroisation represents a trade-off solution for alternative exchange rate regime. If the country accepts unilateral euroisation, monetary policy regime becomes exogenous factor on which national political public has no impact, which in turn, prevents any political controversy with elections.

Despite the advantages, euroisation has its negative consequences which are evident in unforeseen costs and risks.

a. Costs of euroisation

The biggest costs of euroisation are losing the seigniorage and the role of the central bank as lender of last resort. The seigniorage (Segniorage) is the difference between the nominal value of money and the cost of their production. Maastricht Treaty defines the seigniorage revenues to be divided between the Member States (but not for the countries that have accepted the euro on a unilateral basis). Next cost of unilateral adoption of the euro is the loss of foreign exchange reserves that must be spent to pull the domestic currency. If the hyperinflation devaluates the national currency, than the cost of losing foreign exchange reserves are small (Bishev and Boshkov, 2015).

Although the biggest cost of euroisation is the loss of seigniorage, it should not overlook the fact that the seigniorage could be negative, also. One reason for the negative seigniorage lies in the depreciation of the domestic currency. Another factor that could lead to reduction of emission income is the change in the exchange rates of international currencies where national reserves are held. For example, if the euro appreciate, the domestic currency will depreciate and emission gain could be negative.

b. The role of the central bank as lender of last resort

With the unilateral introduction of the euro, the central bank loses the function lender of last resort. In economic terms, the function of a central bank as lender of last resort means approval of emergency loans for liquidity of the bank in crisis conditions, which have a degree of urgency and without them can occur problems that are threat for the target bank system. The role of the lender of last resort is much more difficult with logistical problems, because of performing a number of key services and the execution of payments in large amounts. Thus the country is forced to rely solely on private arrangements with credit institutions. In the absence of the central bank as lender of last resort, the solution would be: 
- domestic banking system owned by foreign banks, will provide the necessary funds if the bank falls into illiquid condition;

- $\quad$ the remaining reserves after euroization are exploited for establishing special funds responsible for solving crisis situations and bridging the problem of insolvency of the bank;

- increasing the requirements for liquidity, efficiency and supervision in the banking sector in accordance with international standards.

c. Costs related to currency stability

As an exceptional and primary objective of the central banks in developed countries is the indication of the price stability. The initial positive effects of euroisation that could be seen in the reduction of inflation and currency stability have adverse effects, too. They are shown in reducing economic growth and employment.

d. Losing monetary policy instruments and exchange rate policy

Under fixed exchange rates, the elimination of shocks requires changes in wages and prices. The economy may fall into recession and decrease in the economic growth due to the absence of flexible wages and prices. The euroised countries, despite the loss of running monetary policy, have no impact on the monetary policy of the ECB. Euroisation includes the risk of non-equilibrium exchange rate, which is even greater because there is no strategy of return. Any deviation of the real exchange rate from the equilibrium has negative effects on the interest rate, GDP, employment.

e. Economic crisis

Structural characteristics of the country under unilateral euroisation, play a key role in defining the balance of benefits and costs of euroisation (Herrero and Glöckler, 2000). There are a number of possible activities and guidelines why the country should adopt unilateral euroisation for accommodating the existing restrictions. First, in a weak banking system, the individual bank is in a difficult situation for independently adjustment, so by adequate efforts should be established a certain banking group. Secondly, this trend of banks concentration is inspired by growing share of foreign banks in the capital of local banks. In the absence of central bank and credit for liquidity, the insolvency of domestic banks amid crisis and shocks could be saved by the concerns of foreign banks for their capital. In the moment of pressure on bank liquidity, the internationalized banks can quickly and easily obtain foreign currency and secure their liquidity position.

Furthermore, due to the lack of central bank supervision, it is necessary to establish an agency that will provide strict regulation and enforcement of banking supervision, so that interest rates will lead to a reasonable framework and improvement of the financial sector stability. Due to the danger of losing deposits in one bank can lead to disruption of the entire banking system. It is necessary to pass a law for the protection of deposits. Also, it is necessary to establish an institution that will act as lender of last resort, and whose foreign assets will amount to $100 \%$ of the reserve money. Of course, in the absence of policy exit it is necessary to define a clear exit strategy from the crisis, if this proves inevitable. The strategy should have several stages, starting from switching to another currency, or creating new instruments of economic policy, increasing the flexibility of the government, leaving the monetary rules and joining some form of regional monetary integration.

Summarizing all the advantages and disadvantages should be noted that unilateral euroisation is one of the alternative forms of monetary authorities. The idea of introducing the euro in the countries of Central and Eastern Europe initially perceived as short path in the euro zone, European Union has not stressed that the introduction of the euro is not a sufficient condition for monetary integration and proposed three stages of monetary integration.

\section{Euroisation in Western Balkans}

Talking about the process of euroisation in the Western Balkan countries, there are de jure and the facto euroisation. As it was mentioned above, financial and real euroisation remains high in the Western Balkans (Figure 1). 


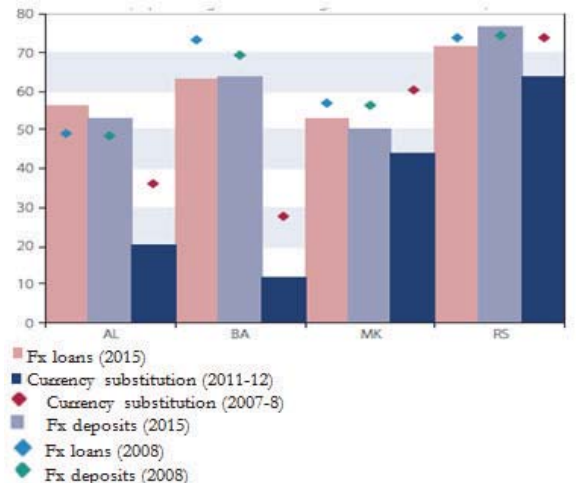

Figure 1. Financial and real euroisation (in percentage)

Sources: National central banks and authors estimations

The process of euroisation in the Western Balkan countries is connected with history of macroeconomic and political disturbances and having no trust in legislation. Also, here is another fact - discouraging saving in domestic currency because of the hyperinflation in the past (Beckmann and Scheiber, 2012). Further, all these countries suffered from various crisis (economic, political, social) during the period of transition (Brown and De Haas, 2010).

Because of the persistence of foreign capital inflows which underline the access to FX-lending with low interest rates, the liability of balance sheets of the banks was characterized with FX-indexed. The opinion since that period was that fixed exchange rate offers stability which is common for the present too.

Taking into account that Western Balkan countries are on the road to EU, it's normally to recognize the reinforcing of the euro and expectation to adopt the euro in future (depending of the status of the country) (ECB, 2014). So, this is the reason to dominate FX-denominated deposits (De Haas, 2015). This situation is very important for the financial system. This acting of central bank as lender of last resort is restricted because weakening the monetary transmission channel makes small room for the central bank to influence on macroeconomic aggregates (Orszaghova, 2014a).

Greater use of domestic currency in the Western Balkan countries will not weaken the euro adoption because all of them are with the same goal - European Union.

\section{Euroisation in Macedonian economy}

Tackling about euroisation in Macedonian economy, we show the deposits of the households in foreign currency (Figure 2). FX deposits of households/total of households show that after initial pick up of the deposits in foreign currency in the first wave of the crisis, they gradually reduced afterwards. The process of stabilization of the declining trend started in the second quarter of 2015.

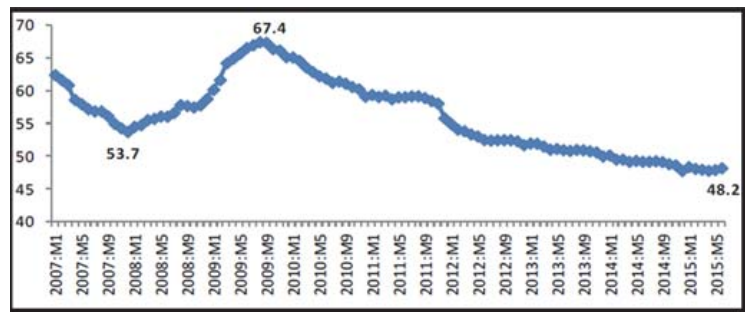

Figure 2. FX deposits of households/total deposits of households (\%) Source:NBRM

Analyzing the banks' deposits and credits currency structure on the liabilities side reflected on the assets side, could be concluded that there is dominant contribution of the Denar component (Figure 3 and Figure 4). 


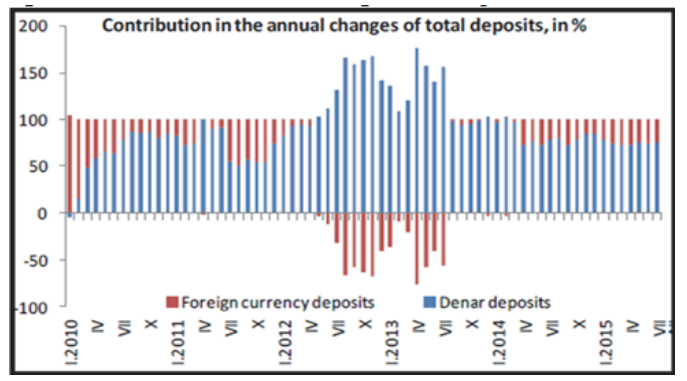

Figure 3. Contribution in the annual changes of total deposits, in \% Source: NBRM

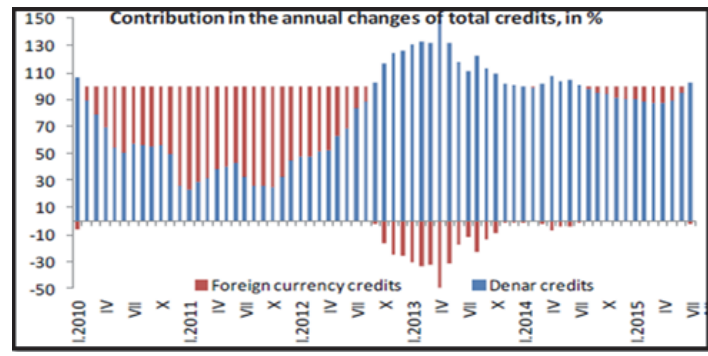

Figure 4. Contribution in the annual changes of total credits, in \% Source: NBRM

Macedonian banking system is characterized with long FX position, while foreign liabilities to non-residents are usually small or less than $10 \%$ of the total liabilities (Figure 5). In the acute stage of the global crisis, banks widened the spread between the Denar and FX deposit interest rates, but in the last years there is a trend of gradual spread reduction. The Central bank of Macedonia - NBRM shows measures in supporting the trend of de-euroisation (Figure 6). For achieving greater progress towards Euroisation is necessary more time. But the history of countries that had successfully deeuroisation is mainly with flexible exchange rate regime. Examples are Chile, Israel, Mexico and Poland (Reinhart et. al., 2003).

Since Macedonia has strong commitment for fixed exchange rate which is pegged to the euro, this can be credible reason to be harder for rapid de-euroisation. Macedonia's long-term commitment for joining the EU and eventually the euro area, adds credibility to the exchange rate regime and makes a move towards more exchange rate flexibility. Deeuroisation should be supported by macroeconomic stability, public debt management and development of the domestic financial market. For example, Israel, Chile and Poland, the process of de-euroisation have been started by reducing inflation and gradually stabilization of the economy as liberalization of the financial sector and capital account.

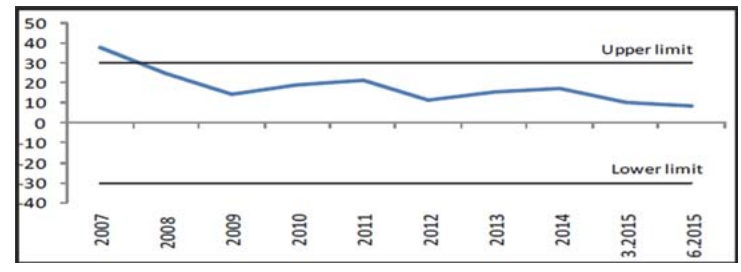

Figure 5. Assets and liabilities with FX component gap / banks' own funds (in \%) Source: NBRM and authors compilation 


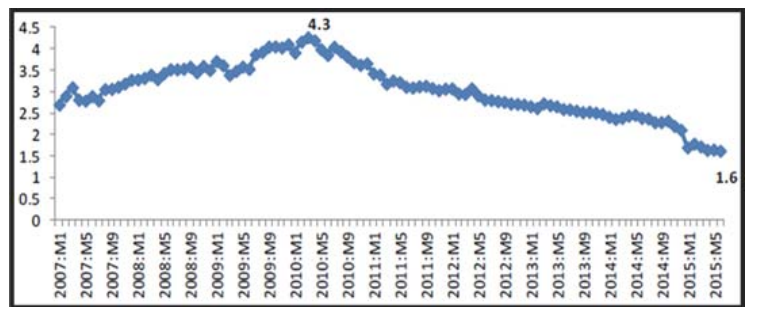

Figure 6. Interest rate spread between denar and foreign currency deposit rate (in p.p.)

Source: NBRM and authors compilation.

Tabel 1. Reserve adequacy ratios for Macedonia (2012-2020)

\begin{tabular}{lccccccccc}
\hline & 2012 & 2013 & 2014 & 2015 & 2016 & 2017 & 2018 & 2019 & 2020 \\
\hline Reserve/STD(percent) & 101.0 & 106.5 & 115.9 & 111.5 & 121.3 & 118.5 & 120.6 & 134.4 & 133.2 \\
Reserve/Months of prospective import goods & 6.2 & 5.2 & 6.0 & 5.2 & 5.2 & 5.2 & 5.0 & 4.6 & 4.8 \\
Reserve/Broad money (percent) & 50.7 & 43.7 & 48.3 & 44.1 & 45.4 & 45.3 & 42.0 & 39.0 & 37.0 \\
Expanded "Greenspan-Guidotti" metric:Reserves/(STD+CA deficit) & 91.6 & 98.8 & 110.0 & 97.7 & 100.9 & 100.0 & 103.1 & 113.6 & 112.9 \\
Reserves/Fund combination metric (percent) & 135.1 & 125.3 & 133.3 & 123.2 & 123.4 & 196.4 & 191.0 & 187.6 & 187.4 \\
\hline
\end{tabular}

A tightening of monetary policy was recommended by IMF to demand pressures pick up or risks to financial stability emerge (IMF, 2015). The policy that is recommended by IMF could also be useful for preserving de-euroisation but should negatively impact the conversion of deposits from FX to domestic currency. According this, Table 1 shows concern for dampening external instability.

Credit history of the bank must contain all relevant details for the bank to establish the identity, creditworthiness, orderliness to perform its obligations and quality of collateral, including the approval and monitoring of exposures that are part of the retail portfolio and analyzes of exposure to the debtor of the exchange rate risk.

The reports show that since 2009 differentiation of the reserve requirement ratios and additional differentiation since mid-2013, are in favor of liabilities in domestic currency. Starting from 2012 there are zero reserve requirements on deposits of households over 2 years to support long-term savings. 2015 is period where zero reserve requirements on Denar deposits of households over one year, support long-term savings in domestic currency (Figure 7).

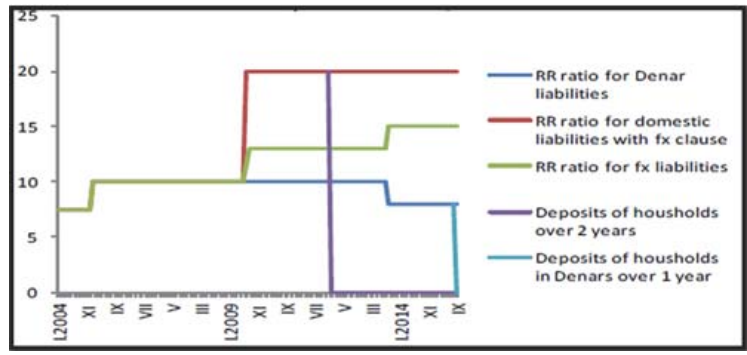

Figure 7. Reserve requirements ratio, in \%

Source: NBRM

Macedonia is able to achieve macroeconomic stability under a fixed exchange rate and prudent fiscal policy in recent years. Macedonia has managed the global crisis relatively well. Active public debt managing and development of the domestic financial market are important policies in supporting the process of de-euroisation. The issuance of local currency-denominated public debt may be de-euroised balance sheet of the government as extend of the yield curve of domestic currencies. The development of deep and liquid domestic financial market will increase the range of local currency - denominated securities and may contribute for reducing the foreign exchange denominated assets (foreign currency deposits)(Rosenberg and Tripak, 2008). Encouraging the development of the domestic investor base such as pension funds, are likely to be supportive of demand for local currency instruments and markets in the long-term. 
De-euroisation could be a lengthy process and could take in achieving macroeconomic stability. The public tends to have long memories of the crisis episodes in the past, and watch the local currency as risky. Also when the public becomes accustomed to using foreign currency in financial transactions and not internalize the negative externality of using foreign exchange to the economy, de-euroization does not happen automatically, even in the case where the successful macro stabilization increase the attractiveness of the local currency. Prudential regulation should be aimed to resolve the euroisation. This will help for managing the foreign exchange risks in providing buffers and creating soft initiative for de-euroisation.

\section{Estimating the Euroisation}

\subsection{Methodology}

The analysis of the study is based on descriptive statistics and probit and ordered probit regressions as SPSS software. The estimation could be divided in three steps. First is the estimation of FX loans and its share in total private sector loans. Second, we estimate FX loans and its currency denomination. Third, we estimate and show the relationship between FX-deposits and FX-loans.

\subsection{Analysis, results and discussion}

The degree of loan euroisation determines the financial system's exposure to systemic credit risk in the case of large devaluations. As we mentioned above, the results show the share of FX loans in total private sector. For this purpose were taken non-financial corporations and households. From the figure could be seen that in Macedonia, Moldova, Poland, Croatia, Hungary, Romania, Bulgaria, FX loans are denominated in foreign currency, while there are other country as Slovakia, Russia and Czech Republic where FX loans play minor role.

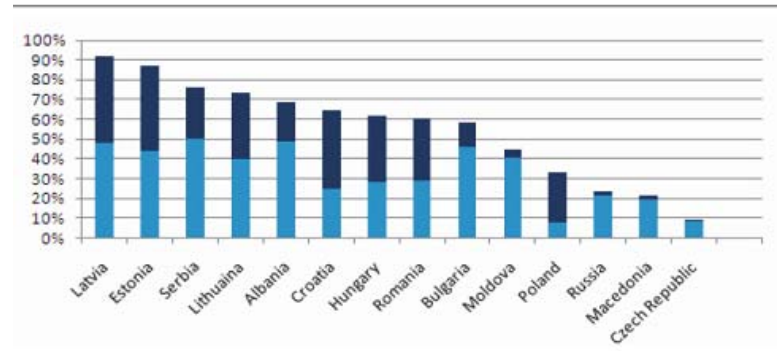

Figure 8: Share of FX loans in nonfinancial corporations and households loans in 2015 Sources: Authors' calculations

Next estimation is presented in Figure 9. Actually, we estimate currency denomination of FX loans. The figure 9 shows that, more than $90 \%$ of all FX-loans in selected countries are denominated in Euro. The other currencies play minor role in the region.

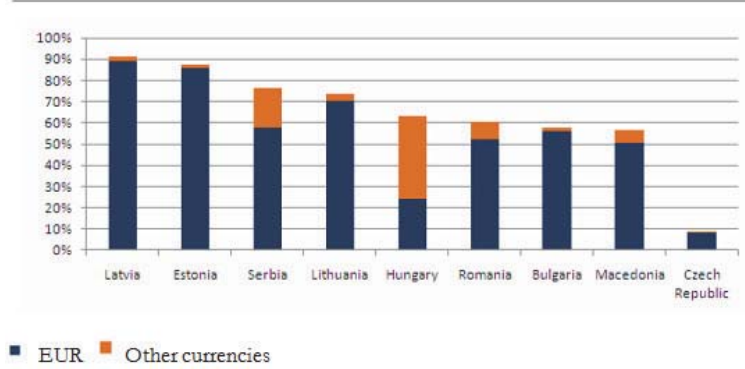

Figure 9: FX-loans and currency denomination, 2015

Source: Authors' calculations 
Banks access to foreign funds determinates their ability to lend domestically in FX. Typically, most of them lend in foreign currency. This will increase the incentives for borrowing in foreign currency. Therefore, we ask an interesting question are foreign banks more engaged in FX lending compared to domestic banks? The results showed strong relationship between FX-deposits and FX-loans (Figure 10).

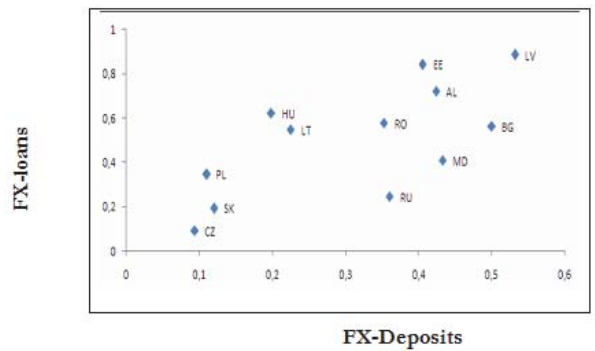

Figure 10: FX-deposits vs. FX-loans, 2015

Source: Authors' calculations

\section{Conclusion}

The focus in this paper was the causes of euroisation in Macedonia. Beyond the incentives for de-euroisation, Macedonia will remain euroised for a long time. The process of euroisation is a problem with a long history and usually persistent phenomena. The main driving forces in Macedonia are the experiences with the savings in the previous system, economic uncertainty in the transition period, external and internal shocks, private transfers inflows in foreign currency. Taking into account that Macedonia has fixed exchange rate pegged to the euro, the confidence in the domestic currency is extremely important. The other facts are that foreign currency holdings are sensitive on economic and non-economic factors, increasing vulnerability of the economy. Also, there is need of regular monitoring of leading indicators in this field and proactive role of the central banks in managing the risks.

The evidences suggest that is difficult to reverse euroisation. This is hard also when macro stability has been well established. There is some regional pattern of euroisation and researchers think that it is related with the region economic integration into EU and aspiration for joining to the euro area.

The best strategy is to provide incentives and supportive macro-financial context for gradual reduction of euroisation, through prudential policies, maintaining macroeconomic stability and developing domestic debt markets. Macedonia has been implementing prudent macroeconomic policies and has achieved macroeconomic stability in the last decade (also, during the global financial crisis). Maintaining such a policy is a pre-requisite of de-euroisation. Given that the pegged exchange rate has limited the scope of monetary policy to respond to the inflation, fiscal policy could play a larger role, by improving public debt management and relying more on longer term denar loans. This would be an important step in fostering the development of domestic debt market. A deep and liquid domestic capital market could provide more investment opportunities in denar as a substitute for FX-denominated assets, thus helping the process of de-euroisation.

\section{References}

Beckmann, E. and Scheiber, T. (2012), "The Impact of Memories of High Inflation on Households' Trust in Currencies", Focus on European Economic Integration Q4/12, OeNB, p. 80-93.

Bishev, Gligor and Boskov, Tatjana (2015) Arguments for and against retaining exchange rate regime: an empirical analysis for Republic of Macedonia. Asian Economic and Financial Review, 5 (8). pp. 1004-1013. ISSN 2305-2147

Bishev, Gligor and Boskov, Tatjana (2015) Export-led growth in SEE6 - Facts and recommandations: The case of Republic of Macedonia. Journal of the Institute of Economics - Economic Development, 17 (3). pp. 277-306. ISSN 1857-7741 (on line) UDK 338

Boskov, Tatjana (2015) How to balance EU convergence \& economic recovery in SEE6. LAP LAMBERT Academic Publishing, Germany. ISBN 978-3-659-74812-7

Boskov, Tatjana (2015) Sustainability of EU convergence based on exchange rate anchor during crisis and post crisis period. Economic recovery in the post-crisis period, 29-30 May 2015, Skopje, Macedonia. 
Boskov, Tatjana and Bishev, Gligor (2015) Impact of exchange rate in the run-up to EU accession: An empirical analysis of Republic of Macedonia. Asian Economic and Financial Review, 5 (12). pp. 1282-1297. ISSN 2222-6737/2305-2147

Brown M. and De Haas R., "Foreign currency lending in emerging Europe: Bank-level evidence", EBRD working paper 122, 2010.

De Haas (2015), Migration and Development: A Theoretical Perspective, International Migration Review, Volume 44, Issue 1, page 227264

ECB: "The international role of the euro", several issues (July 2008 - July 2014).

European Commission (2014), "Screening Report Montenegro: Chapter 17 - Economic and Monetary Policy", MD 29/14, 7.03.2014.

Herrero G.A., Glöckler G., (2000), „Options for Latin America in a globalised World: a regional monetary union versus dollarisation“, European Central Bank, Frankfurt.

International Monetary Fund (2012), Former Yugoslav Republic of Macedonia: Selected Issues, IMF Country Report. No. 12/134, Washington, p.16

International Monetary Fund (2015), Former Yugoslav Republic of Macedonia: Selected Issues, IMF Country Report. No. 12/144, Washington, p.19.

NBRM (2015) Recent Macroeconomic Indicators, Review of the Current Situation.

NBRM (2016), Annual Report.

Orszaghova, L. (2014a), "EU enlargement: Recent economic developments and challenges for EU membership (part II)", Biatec, 22(7), p. 14-21

Reinhart C., Rogoff R., and Savastano M., "Addicted to Dollars", NBER Working Paper 10015, 2003.

Rosenberg C, and Tripak M., (2008), Determinants of Foreign Currency Borrowing in the New Member States, IMF Working Paper, European Depaerment 
ISSN 2039-2117 (online)

ISSN 2039-9340 (print)
Mediterranean Journal of Social Sciences MCSER Publishing, Rome-Italy
Vol 8 No 2

March 2017 